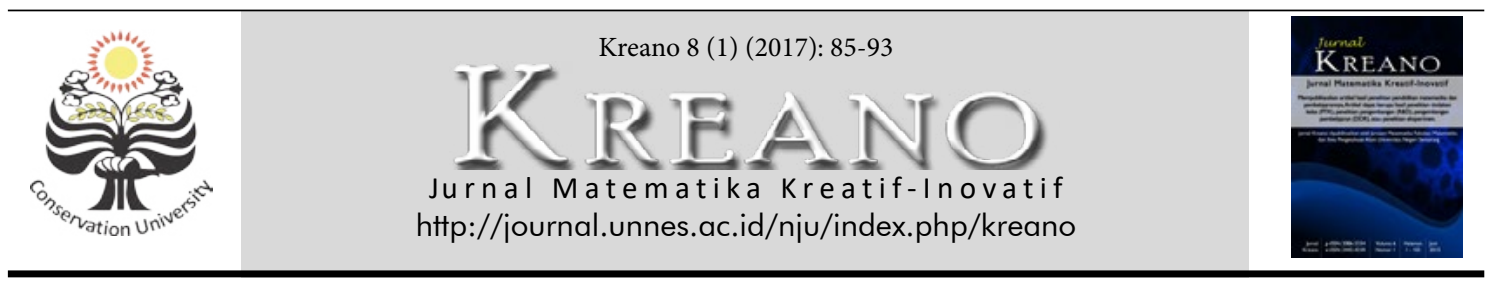

\title{
Profil Berpikir Geometri Siswa Tunagrahita berdasarkan Tingkatan Van Hiele di SMPLB Negeri Salatiga
}

\author{
Ranu Fitra Pradhitya' ${ }^{1}$ Tri Nova Hasti Yunianta², Novisita Ratu ${ }^{3}$ \\ 1,2,3Pendidikan Matematika,Fakultas Keguruan dan Ilmu Pendidikan \\ Universitas Kristen Satya Wacana, Indonesia \\ Email: ranupradhitya@gmail.com',trinova.yunianta@staff.uksw.edu²,novisita.ratu@ \\ staff.uksw.edu ${ }^{3}$ \\ DOI: http://dx.doi.org/10.15294/kreano.v8i2.8068 \\ Received : December 2016; Accepted: April 2017; Published: June 2017
}

\begin{abstract}
Abstrak
Jenis penelitian ini adalah deskriptif kualitatif yang bertujuan untuk mengetahui bagaimana profil berpikir geometri siswa tunagrahita berdasarkan tingkatan berpikir van Hiele. Subjek dalam penelitian ini adalah tiga orang siswa yang terdiri masing-masing satu siswa dari kelas VII, VIII dan IX SMPLB C Negeri Salatiga. Penelitian ini dilakukan melalui wawancara semi terstrukur. Hasil dari penelitian yang dilakukan, ketiga siswa cenderung memiliki kemampuan yang sama dalam berpikir geometri. Ketiga siswa dapat mencapai tingkat 1 (visualisasi) berdasarkan tingkat berpikir geometri van Hiele, namun terbatas pada bentuk-bentuk bangun geometri yang dipahami atau dikenalnya. Siswa belum dapat melakukan analisis pada tingkat 2 dan hanya sebatas mengetahui sebagian komponen pada bangun segiempat serta menamainya menggunakan bahasanya sendiri yang tidak baku. Selain itu siswa mengetahui beberapa istilah yang ada pada bangun segiempat, namun tidak mengetahui maksud dari istilah-istilah tersebut. Kendala dan masalah yang dihadapi ketiga siswa yaitu lebih cenderung memperhatikan pada bangun-bangun yang dikenalnya, kurang cermat dan teliti dalam menggambar, kesulitan dalam menjelaskan atau mendeskripsikan secara lisan suatu bangun segiempat dan hanya terbatas pada bangun yang diketahuinya, hal tesebut karena siswa tidak banyak mengenal macam-macam bangun.
\end{abstract}

\begin{abstract}
This research is a qualitative descriptive which aims to determine how the profile geometry students think retarded by van Hiele levels of thinking. Subjects in this study were three students who comprised each of the students of class VII, VIII and IX SMPLB C State Salatiga. This research was conducted through semi-structured interviews. The results of the research conducted, the three students tend to have the same ability to think geometry. All three students can reach level 1 (visualization) based on the geometry of the van Hiele levels of thinking, but limited to the forms of geometry understood or known. Students have not been able to perform the analysis at 2 and merely knowing some components in the wake of the quadrilateral and named him use his own language is not standardized. In addition, students know some of the terms that exist in the wake of the quadrilateral, but do not know the purpose of these terms. Constraints and problems faced by the three students are more likely to pay attention in the wake familiar, less meticulous in drawing, difficulty in explaining or describing verbally a wake quadrilateral and confined to the waking knew, tesebut because students do not know a lot of Miscellaneous wake.
\end{abstract}

Keywords: geometric thinking; van Hiele; difable

\section{PENDAHULUAN}

Pendidikan merupakan hak setiap warga negara, begitu pula pendidikan bagi anak berkebutuhan khusus dimana mempunyai hak yang sama untuk memperoleh pendidikan seperti tercantum dalam pasal 5 ayat 2 UU No. 20 Tahun 2003 yang menyatakan bahwa warga ne- gara yang memiliki kelainan fisik, emosional, mental, intelektual, dan/atau sosial berhak memperoleh pendidikan khusus. Berdasarkan alasan tersebut pemerintah menyelengarakan sekolah inklusi atau Sekolah Luar Biasa (SLB) untuk melayani kebutuhan pendidikan bagi anak berkebutuhan khusus (student with 
special needs).

Anak Berkebutuhan Khusus (ABK) merupakan istilah lain untuk menggantikan kata "Anak Luar Biasa (ALB)" yang menandakan adanya kelainan khusus (Delphie, 2006). Menurut klasifikasi dan jenis kelainan, anak berkelainan dapat dikelompokkan ke dalam kelainan fisik, kelainan mental, dan kelainan karakteristik sosial.

Istilah anak berkelainan mental dalam beberapa referensi banyak juga disebut terbelakang mental, kelainan mental, lemah ingatan, cacat mental, mental subnormal, anak dengan gangguan perkembangan (child with development impairment) atau tunagrahita (Somantri, 2006). Tunagrahita adalah istilah yang digunakan untuk menyebutkan anak yang mempunyai kemampuan intelektual di bawah rata-rata. Anak yang berkelainan mental dalam arti kurang atau tunagrahita, yaitu anak yang diidentifikasi memiliki tingkat kecerdasan yang sedemikian rendahnya (di bawah normal) sehingga untuk meniti tugas perkembangannya memerlukan bantuan atau layanan khusus, termasuk di dalamnya kebutuhan program pendidikan dan bimbingan (Efendi, 2009). Anak tunagrahita memiliki kelemahan pada aspek intelejensinya, indikasinya dapat dilihat pada angka hasil tes kecerdasan, seperti IO 0-25 dikategorikan mampu rawat, IO 25-50 dikategorikan mampu latih, IO 50-75 dikategorikan mampu didik (Efendi, 2009).

Anak tunagrahita memiliki masalah belajar yang disebabkan adanya hambatan perkembangan intelegensi, mental, sosial dan fisik (Delphie, 2006). Anak tunagrahita atau terbelakang mental karena keterbatasan kecerdasannya mengakibatkan dirinya sukar untuk mengikuti program pendidikan di sekolah biasa secara klasikal, oleh karena itu anak terbelakang mental membutuhkan layanan pendidikan secara khusus yakni disesuaikan dengan kemampuan anak tersebut. Pendidikan khusus bagi anak tunagrahita ringan disebut juga SLB C. Peserta didik berkelainan seperti tunagrahita yang memiliki kemampuan intelektual di bawah rata-rata, memiliki kurikulum yang sangat spesifik, sederhana dan bersifat tematik untuk mendorong kemandirian dalam hidup sehari-hari (BSNP, 2006).

Siswa yang mengalami kelainan se- perti tunagrahita tentunya juga akan banyak mengalami kesulitan belajar, salah satunya mengalami kesulitan dalam belajar matematika. Apalagi dari berbagai bidang studi yang diajarkan di sekolah, matematika merupakan bidang studi yang dianggap paling sulit oleh para siswa (Abdurrahman, 2010). Pelajaran matematika juga menjadi salah satu mata pelajaran yang diajarakan di SMPLB C. Ruang lingkup pelajaran matematika yang diajarkan di SMPLB C meliputi aspek-aspek bilangan, geometri dan pengukuran, aljabar, peluang dan statistika.

Salah satu cabang kajian dalam matematika adalah geometri. Geometri merupakan ilmu matematika mengenai bangun, bentuk, dan ukuran benda-benda (Bramasti, 2012; Kerami, 2003). Dilihat dari sudut pandang psikologi, geometri merupakan penyajian abstraksi pengalaman visual dan ruang, misalnya bidang, pengukuran, dan pemetaan. Oleh karena itu, banyak tes psikologi yang melibatkan unsur geometri, misalnya tes 10 dan tes gaya kognitif (Sutama et al, 2014). Geometri dianggap penting karena teknik-teknik geometri dapat membantu memecahkan masalah dari cabang-cabang matematika yang lain. Tujuan pembelajaran geometri sendiri secara umum adalah agar siswa memperoleh rasa percaya diri mengenai kemampuan (keterampilan) matematikanya, menjadi pemecah masalah yang baik, dapat berkomunikasi secara matematis, dan dapat bernalar secara matematis (Muhassanah, 2014). Geometri juga banyak ditemukan dalam kehidupan sehari-hari oleh anak tunagrahita seperti anak normal pada umumnya, seperti garis, bangun, bentuk, ukuran-ukuran bangun dan sebagainya. Cabang geometri merupakan salah satu cabang matematika yang masuk ke dalam ilmu terapan sehingga dapat membantu dan bermanfaat dalam kehidupan sehari-hari, begitu pula bagi anak berkebutuhan khusus seperti tunagrahita.

Seperti di sekolah pada umumnya, pembelajan matematika di SMPLB C juga mengajarkan materi geometri seperti bangun datar dan bangun ruang. Bangun datar yang diajarkan pada siswa SMPLB C diantaranya mengenai bangun segiempat. Setiap siswa tidak memiliki pemikiran yang sama tentang 
ide-ide pada geometri, sehingga dalam pembelajaran geometri perlu memperhatikan tingkat-tingkat berpikir siswa. Riset dari Pierre van Hiele dan Dina van Hiele-Geldof (Crowley: 1987), telah menghasilkan wawasan tentang perbedaan dalam pemikiran geometri dan bagaimana perbedaan itu muncul. Terdapat beberapa tingkatan dalam berpikir geometri seperti yang diungkapkan van Hiele. Tingkatan tersebut berupa hierarki dalam pemahaman geometri. Tingkatan berpikir geometri menurut van Hiele yaitu visualisasi, analisis, deduksi informal, deduksi dan ketepatan/rigor (Walle, 2007). Tiap tingkatan menggambarkan proses pemikiran yang diterapkan dalam konteks geometri. Tingkatan-tingkatan tersebut menjelaskan tentang bagaimana berpikir dan jenis ide-ide yang dipikirkan, bukannya berapa banyak pengetahuan yang dimiliki (Walle, 2007).

Model berpikir geometri yang dikembangkan van Hiele bermaksud sebagai sarana dalam mengidentifikasi tingkat berpikir geometri siswa dan sarana untuk membantu siswa meningkatkan kemampuan melalui tingkatan berpikir (Crowley, 1987). Oleh karena itu, teori van Hiele dapat membantu dalam memperbaiki dan merencanakan pembelajaran matematika di sekolah, termasuk di sekolah bagi anak berkebutuhan khusus. Hal tersebut juga sesuai dengan hasil penelitian Muhassanah (2014) bahwa keterampilan geometri yang dimiliki siswa berbeda-beda berdasarkan tingkat berpikir van Hiele, untuk itu guru hendaknya merencanakan model pembelajaran yang disesuaikan dengan tingkat berpikir siswa.

Penelitian tentang kemampuan berpikir geometri sebelumnya telah dilakukan pada siswa normal. Penelitian yang dilakukan Lestariyani (2013) menyimpulkan bahwa secara keseluruhan siswa SMP N 2 Ambarawa berada pada tingkat 1 (visualisasi) dan 2 (analisis) dalam berpikir geometri berdasarkan teori van Hiele. Sementara penelitian yang dilakukan Maulani (2014) di MTsN Batu Tebal memperoleh hasil siswa laki-laki mampu berfikir sampai tingkat 3 dengan baik dan siswa perempuan mampu berfikir sampai tingkat 3 dengan cukup baik, yaitu deduksi informal.

Lemahnya kemampuan yang dimiliki siswa tunagrahita membuat mereka mengalami kesulitan memahami konsep-konsep dalam geometri. Hal tersebut juga didukung oleh penelitian yang dilakukan Anggraeny (2014) bahwa anak tunagrahita mengalami kesulitan memahami bentuk bangun ruang dan mengidentifikasinya apabila bangun tersebut disusun secara vertikal dan horizontal, secara berjajar dan diberi warna. Penelitian yang dilakukan Utami (2014) juga menyatakan karakteristik anak tunagrahita adalah ketidakmampuan dalam berpikir abstrak dan mudah lupa.

Salah satu SLB yang ada di Salatiga adalah SLB Negeri Salatiga yang menyelengarakan program pendidikan luar biasa dari jenjang TKLB sampai SMALB. Berdasarkan hasil wawancara yang dilakukan kepada salah satu guru yang mengajar di SMPLB C Negeri Salatiga, gejala yang sama juga dialami siswa di sekolah tersebut. Siswa mengalami kendala dalam belajar matematika, terutama dalam memahami konsep-konsep dalam matematika, selain itu siswa juga mudah lupa setelah pelajaran diberikan sehingga sering mengulangi materi yang sama pada pertemuan berikutnya.

Beberapa siswa SMPLB C Negeri Salatiga pada awalnya tidak berasal dari SDLB C, namun kemudian dirujuk untuk sekolah di SLB karena mengalami kesulitan dalam mengikuti pelajaran di sekolah. Permasalahan tersebut dikarenakan ketidaktahuan guru dan orang tua mengenai kondisi siswa sejak awal ataupun keluarga yang tidak bisa menerima kondisi anaknya. Kondisi ketunagrahitaan dalam praktik kehidupan sehari-hari dikalangan awam seringkali disalahpersepsikan, terutama bagi keluarga yang mempunyai anak tunagrahita, yakni berharap dengan memasukkan anak tunagrahita ke dalam lembaga pendidikan, kelak anaknya akan berkembang sebagaimana anak normal lainya (Efendi, 2009). Harapan tersebut wajar, karena banyak masyarakat tidak mengetahui karakteristik anak tunagrahita. Perlu dipahami bahwa kondisi tunagrahita tidak dapat disamakan dengan penyakit, atau berhubungan dengan penyakit, tetapi keadaan tunagrahita suatu kondisi sebagaimana yang ada, "Mental retarded is not disease but a condition" (Efendi, 2009).

Berdasarkan permasalahan yang telah dipaparkan, perlu dilakukannya penelitian mengenai "Profil Berpikir Geometri Siswa 
Tunagrahita Berdasarkan Tingkatan van Hiele di SMPLB Negeri Salatiga". Hasil penelitian ini diharapkan dapat memberikan gambaran mengenai kemampuan belajar siswa yang memiliki masalah dalam perkembangan, sehingga dapat membantu guru maupun sekolah dalam memperbaiki dan merencanakan progam pembelajaran bagi anak berkebutuhan khusus seperti tunagrahita.

\section{METODE}

Penelitian ini dilakukan di SLB Negeri Salatiga Jalan Hasanudin Gang III Banjaran, Mangunsari, Salatiga. Penelitian dilakukan pada bulan Januari sampai Mei 2015. Penentuan subjekdalam penelitian ini menggunakan teknik purposive sampling yaitu teknik pengambilan sampel dengan pertimbangan tertentu (Sugiyono, 2013: 124).Subjek penelitian terdiri dari 3 siswa tingkat SMPLB C yang termasuk dalam klasifikasi tunagrahita ringan (mampu didik) sehingga mereka masih bisa belajar membaca, menulis, dan berhitung sederhana dan secara fisik tampak seperti anak normal pada umumnya. Ketiga subjek tersebut yaitu: (a) siswa ANF adalah siswa laki-laki kelas VII C yang berumur 14 tahun, siswa tersebut memiliki respon cepat, mudah dalam menangkap suatu pertanyaan atau instruksi, dan bisa berkomunikasi dengan baik, walaupun mengalami kesulitan dalam pengucapan kata-kata yang sukar; (b) AAP adalah siswa laki-laki kelas VIII C yang berumur 17 tahun, siswa tersebut pendiam, namun mudah menangkap pertanyaan atau instruksi, cukup teliti dalam mengerjakan suatu pekerjaan, serta dapat berkomunikasi dengan baik; (c) MAY adalah siswa laki-laki kelas IX C yang berumur 19 tahun, siswa tersebut mudah menangkap pertanyaan atau instruksi, bagus dalam berkomunikasi tapi mengalami kesulitan dalam pengucapan kata-kata yang sukar.

Penelitian ini menggunakan teknik triangulasi dalam pengumpulan data, yaitu dengan observasi tidak terstuktur, wawancara semi terstruktur, dan dokumentasi. Instrumen dalam penelitian ini adalah peneliti sendiri yang didukung oleh pedoman wawancara beserta alat yang digunakan untuk aktivitas siswa dalam wawancara dimana sudah divalidasi oleh tiga validator yang terdiri dari dosen pendidikan matematika, praktisi pendidikan matematika dan guru SLB N Salatiga. Pedoman wawancara yang dibuat mengacu pada kemampuan berpikir geometri berdasarkan tingkatan van Hiele seperti pada Tabel 1.

Tabel 1. Deskripsi Kemampuan Berpikir Geometri van Hiele

\begin{tabular}{|c|c|}
\hline Tingkat & Deskripsi \\
\hline Visualisasi & $\begin{array}{l}\text { Mengidentifikasi, menamai, mem- } \\
\text { bandingkan dan mengolah bangun } \\
\text { pada geometri berdasarkan tampi- } \\
\text { lannya. }\end{array}$ \\
\hline Analisis & $\begin{array}{l}\text { Menganalisis istilah-istilah dari } \\
\text { bangun geometri dari komponen- } \\
\text { nya dan hubungan antar komponen } \\
\text { serta menemukan sifat/aturan dari } \\
\text { kelompok bentuk secara empiris. }\end{array}$ \\
\hline $\begin{array}{l}\text { Deduksi } \\
\text { informal }\end{array}$ & $\begin{array}{l}\text { Siswa secara logis mengaitkan apa } \\
\text { yang diperoleh sebelumnya untuk } \\
\text { menemukan sifat/aturan dengan } \\
\text { memberikan atau mengikuti dalil- } \\
\text { dalil informal. }\end{array}$ \\
\hline
\end{tabular}

Teknik analisis data dalam penelitian ini menggunakan teknik Miles dan Huberman (Sugiyono, 2010) yaitu data reduction, data display, dan conclusion drawing/verification. Keabsahan data dalam penelitian ini dijamin menggunakan triagulasi sumber. Teknik ini dilakukan dengan mengkomunikasikan data yang telah diperoleh dari peneliti pada dosen pembimbing, dan dari peneliti pada guru yang mengajar matematika di kelas.

\section{HASIL DAN PEMBAHASAN}

Tingkatan berpikir geometri terdapat 5 tingkatan menurut van Hiele yaitu visualisasi, analisis, deduksi informal, deduksi dan ketepatan/ rigor. Penelitian yang dilakukan menunjukkan ketiga siswa masih mencapai tingkat berpikir geometri yang sama yaitu tingkat 1 (visualisasi) berdasarkan tingkat berpikir geometri van Hiele. Berdasarkan penelitian yang dilakukan terhadap tiga subjek menunjukkan profil berpikir sebagai berikut ini.

\section{Profil BerpikirGeomerti Siswa ANF Visualisasi}

Siswa ANF diberikan berbagai bangun datar dengan berbagai bentuk, ukuran dan warna, kemudian siswa ANF diminta untuk menge- 
lompokkannya berdasarkan keinginannya atau yang dianggapnya menarik. Hasilnya siswa ANF mengidentifikasi bentuk bangun geometri dengan mengelompokkannya berdasarkan bentuk dan dapat memberikan alasan sesuai pemahamanya yaitu dengan menghitung sudutnya. Siswa ANF juga dapat mengelompokkan bangun segiempat karena kemiripannya dan bentuknya seperti persegi, persegipanjang, belahketupat, jajargenjang, trapesium dan layang-layang seperti pada Gambar 1. Hal tersebut menunjukkan siswa ANF dapat mengidentifikasi bangun-bangun segiempat secara keseluruhan.

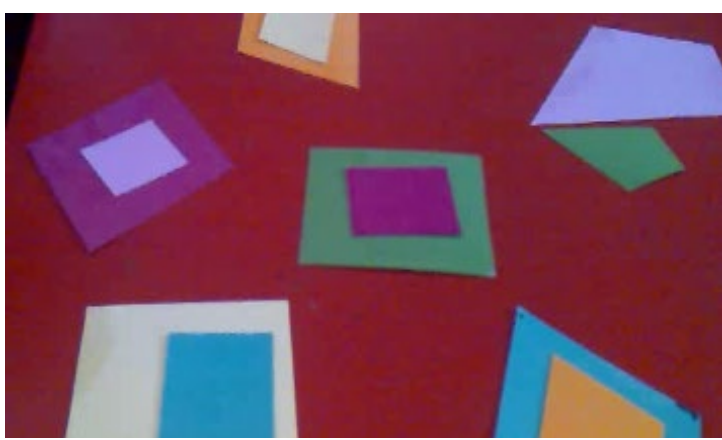

Gambar 1. Pengelompokkan Bentuk yang Dilakukan Siswa

Siswa ANF juga dapat dengan tepat menyebutkan baberapa bangun yang ada pada gambar/objek nyata yang diberikan. Siswa ANF dapat menemukan bentuk bangun persegi, persegipajang dan layang-layang, namun siswa kesulitan ketika menemukan bangun trapesium, siswa lupa atau tidak mengetahuinya sehingga tidak mengenal bangun tersebut. Hal tersebut menunjukkan siswa ANF tertarik atau cenderung lebih memperhatikan bentuk-bentuk yang dikenalinya seperti pada Gambar 2.

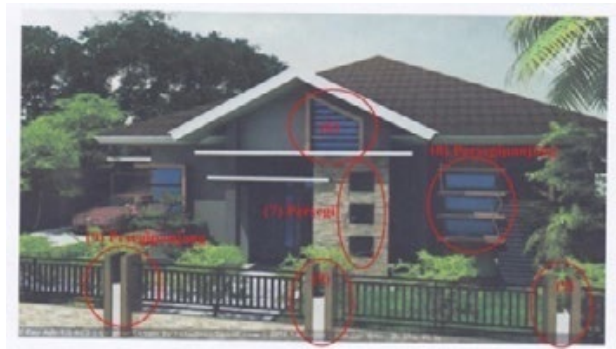

Gambar 2. Bentuk Segiempat pada Objek Nyata
Sementara ketika siswa ANF diminta untuk meniru suatu bangun segiempat yang dilihatnya dan menggambar bangun segiempat berdasarkan instruksi yang diberikan, siswa ANF cukup baik melakukannya. Hanya saja siswa kurang cermat dan teliti sehingga hasilnya kurang tepat. Hasil kerja siswa dapat dilihat pada gambar 3 .

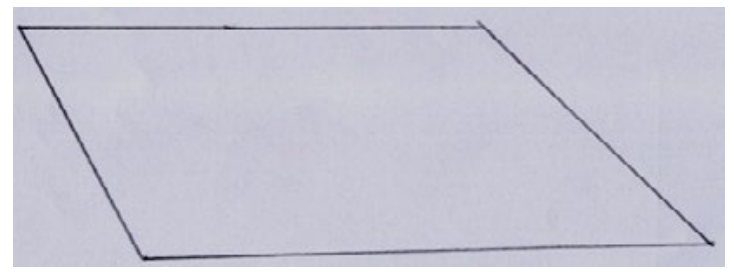

Gambar 3. Gambar Segiempat

Kemampuan visualisasi lain yang dapat diketahui ketika siswa ANF diminta memilah bangun segiempat yang menurutnya memiliki kemiripan dan kemudian diminta untuk menunjukkan persamaan dan perbedaannya. Hasilnya siswa ANF dapat memilah dan membandingkan bangun segiempat berdasarkan penampilan secara keseluruhan. Siswa menunjukkan dan menyebutkan beberapa persamaan serta perbedaan menggunakan bahasanya sendiri yang tidak baku seperti mempunyai empat pucuk, lebih panjang, ataupun menggunakan istilah diseparo/dipotong miring. Hanya saja siswa ANF kesulitan ketika diminta menjelaskan secara lisan. Sementara ketika siswa ANF diminta mendeskripsikan dan menamai suatu bangun segiempat dengan penampilan secara keseluruhan, siswa ANF mendeskripsikandan menamai suatu bangun segiempat menggunakan bahasanya sendiri, misalnya persegi seperti kertas kotak dan persegipanjang seperti buku. Kendala yang dihadapi siswa ANF dapat mendeskripsikan bangun segiempat terbatas pada bangun yang dikenalnya, siswa ANF terkendala ketika menggambarkan bangun yang tidak diketahuinya karena siswa ANF tidak banyak mengenal macam-macam bangun.

Kemampuan siswa ANF dapat dengan baik memecahkan masalah yang berhubungan dengan aspek visualisasi. Hal tersebut dapat diketahui ketika siswa dapat dengan baik membentuk atau mengolah potongan bangun segitiga untuk membentuk sebuah 
bangun segiempat yang diminta dan menghitung luas persegipanjang dengan satuan luas persegi melalui pengubinan (Gambar 4).

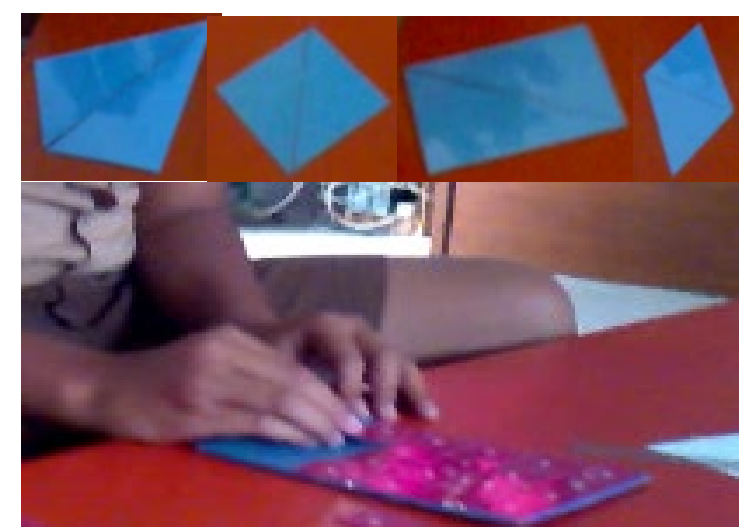

Gambar 4. Pemecahan Masalah yang dilakukan Siswa

\section{Analisis}

Berdasarkan hasil penelitian yang telah dilakukan menunjukkan siswa ANF belum mencapai tingkat analisis. Hal tersebut dikarenakan siswa ANF belum dapat mengidentifikasi komponen-komponen pada bangun datar segiempat. Hasil penelitian menunjukkan siswa ANF belum memahami yang dimaksud sisi, siswa masih memahami bahwa bagian yang panjang adalah sisi, sedangkan yang pendek bukanlah sisi. Siswa ANF juga belum memahami yang dimaksud dengan sudut, siswa masih memahami dengan bahasa sendiri sebagai pucuk. Begitu pula dengan diagonal, siswa mengaku tidak mengetahuinya. Masalah tersebut membuat siswa ANF belum dapat mendeskripsikan hubungan diantara komponen dan sifat pada bangun segiempat. Siswa ANF hanya mampu membandingkan antarbangun menggunakan bagian yang terlihat atau visual menggunakan bahasanya sendiri yang tidak baku seperti lebih panjang, miring ataupun lurus.

\section{Profil Berpikir Geomerti Siswa AAP}

\section{Visualisasi}

Siswa AAP diberikan berbagai bangun datar dengan berbagai bentuk, ukuran dan warna, kemudian siswa diminta untuk mengelompokkannya berdasarkan keinginannya atau yang anggapnya menarik. Hasilnya siswa AAP mengidentifikasi bentuk bangun dengan mengelompokkannya berdasarkan bagian bangun yang terlihat menonjol seperti lancip atau bundar. Masalah yang ditemukan menunjukkan siswa akan lebih mudah mengidentifikasi bangun yang memiliki karakteristik atau bagian yang menonjol dan kesulitan mengelompokkan bangun yang tidak memiliki bagian yang menonjol, hasilnya dapat dilihat pada Gambar 5 .

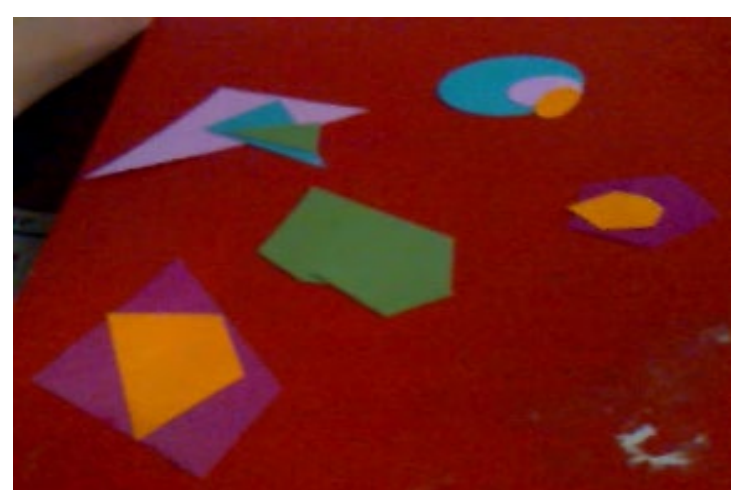

Gambar 5. Siswa Mengelompokkan Bangun Datar

Siswa AAP juga mengelompokkan bangun berdasarkan jumlah sisi yang dimiliki dan kemiripan bentuknya. Sementara untuk segiempat siswa AAP dapat mengelompokkan dengan baik untuk beberapa bangun yaitu persegi, persegi panjang, layang-layang, dan kesulitan mengidentifiksi bentuk segiempat yang lain.

Kemampuan siswa AAP cukup baik dalam mengidentifikasi bentuk pada objek nyata. Siswa AAP dapat menyebutkan beberapa bangun yang ada pada gambar yang memuat bentuk-bentuk bangun geometri. Hasil penelitian menunjukkan siswa cenderung lebih memperhatikan pada bangun kotak, persegipanjang dan jajargenjang dimana bangunbangun tersebut yang pahaminya. Siswa juga mengalami kesalahan dalam penyebutan dimana bentuk-bentuk yang miring dinamai jajargenjang, dikarenakan siswa memahami bangun yang miring adalah jajargenjang. Contoh hasil siswa dalam mengidentifikasi bentuk pada objek nyata dapat dilihat pada Gambar 6. 


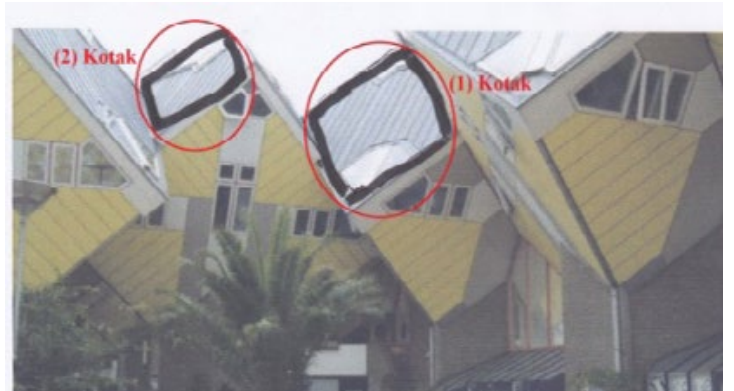

Gambar 6. Bentuk Segiempat pada Objek Nyata

Sementara kemampuan siswa AAP dapat mengidentifikasi dengan baik bangun geometri secara visual dengan cara menggandakan/meniru dan menggambar suatu bangun segiempat. Hal tersebut dapat dilihat dengan siswa AAP dapat dengan baik meniru bentuk bangun segiempat seperti yang dicontohkan dan menggambar bentuk bangun segiempat yang diinstruksikan, namun siswa AAP mengalami masalah dengan kecermatan dan ketelitian, sehingga mengalami kesalahan dalam mengidentifikasi melalui menggambar bangun geometri. Contoh hasil menggambar siswa dapat dilihat pada Gambar 7.

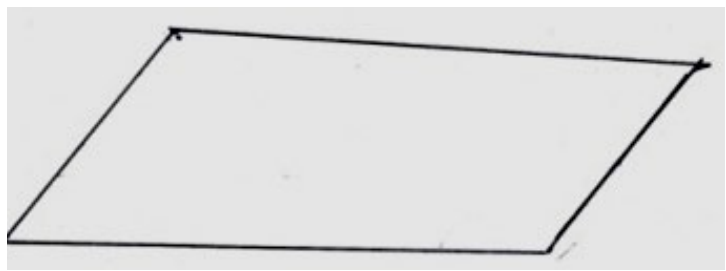

Gambar 7. Gambar Segiempat

Kemampuan visualisasi lain siswa AAP adalah memilah dan membandingkan bangun segiempat yang memiliki kesamaan, hal tersebut dapat dilihat dengan siswa AAP dapat menunjuk jajargenjang dan belahketupat, serta persegi dan persegipanjang ketika diminta mencari bangun yang mirip dan memberikan beberapa alasannya. Hanya saja siswa mengalami masalah ketika diminta untuk menjelaskan secara lisan tentang kemiripan dan perbedaannya. Sementara ketika siswa AAP diminta mendeskripsikan suatu bangun segiempat baik dengan baku ataupun bahasanya sendiri, kemampuannya terbatas hanya pada bangun yang diketahuinya yaitu persegi dan persegipanjang. Siswa AAP mengalami hambatan ketika diminta menjelaskan atau memberikan contoh secara lisan suatu bangun segiempat secara keseluruhan. Selain itu siswa AAP sering lupa, hal tersebut dapat dilihat ketika siswa AAP tidak dapat memberikan contoh maupun memberikan deskripsi tentang bangun yang diminta, namun siswa dapat memberikan deskripsi ketika melihat bangun yang dimaksud.

Siswa AAP juga dapat dengan baik memecahkan masalah yang berhubungan dengan kemampuan visualisasi. Hal tersebut dapat dilihat ketika siswa AAP dapat membentuk bangun segiempat yang diminta menggunakan dua potongan segitiga. Siswa juga dapat dengan baik menghitung luas persegipanjang dengan menggunakan satuan luas persegi melalui pengubinan (Gambar 8).

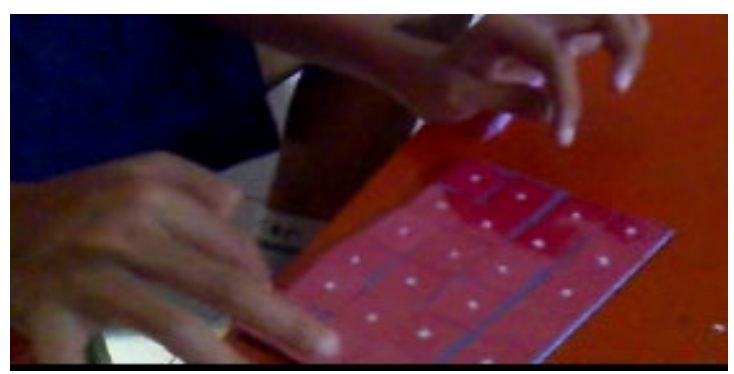

Gambar 8. Siswa Melakukan Pengubinan

\section{Analisis}

Hasil penelitian menunjukkan siswa AAP belum mencapai pada tingkat analisis. Siswa AAP belum memahami yang komponenkomponen dari bangun segiempat seperti sisi, sudut maupun diagonal. Siswa AAP selalu tidak tepat ketika diminta menunjukkan suatu bagian pada bangun segiempat dan menamai bagian bangun dengan menggunakan bahasa sendiri/tidak baku. Siswa AAP masih menggunakan bahasa yang tidak baku untuk mendeskripsikannya yaitu menggunakan istilah garis untuk menggambarkan sisi dan mendeskripsikan secara keseluruhan suatu bangun menggunakan bahasanya sendiri seperti bentuk kotak. Siswa AAP mendeskripsikan persegipanjang garisnya lebih panjang daripada persegi, sementara jajargenjang garisnya miring sedangkan persegipanjang garisnya panjang. Masalah tersebut membuat siswa AAP tidak dapat mendeskripsikan hubungan diantara komponen dan sifat pada segiempat. 


\section{Profil Berpikir Geomerti Siswa MAY}

\section{Visualisasi}

Siswa MAY diberikan berbagai bangun datar dengan berbagai bentuk, ukuran dan warna, kemudian siswa diminta untuk mengelompokkannya berdasarkan keinginannya atau yang dianggapnya menarik. Hasilnya siswa MAY mengidentifikasi bangun geometri yang diberikan dengan mengelompokkannya berdasarkan bagian yang terlihat menonjol seperti lancip atau panjang, namun siswa tidak dapat menjelaskan semua secara lisan tentang bangun-bangun yang dikelompokkanya. Siswa MAY juga mengelompokkan bangun berdasarkan jumlah sisi dan bentuknya. Sementara siswa MAY mengelompokkan segiempat berdasarkan bentuknya seperti persegi, persegipanjang, jajargenjang, belahketupat, trapesium dan layang-layang. Hanya saja siswa tidak dapat menamai semua nama bangun yang dikelompokkannya.

Kemampuan siswa MAY dalam mengidentifikasi bentuk pada objek nyata/gambar dapat dilihat ketika siswa MAY dapat mengidentifikasi bentuk namun cenderung lebih memperhatikan pada bangun-bangun yang dipahaminya. Hal tersebut dapat dilihat ketika siswa MAY hanya menunjuk dan menandai bangun persegi dan persegipanjang dimana bangun-bangun tersebut yang dikenalinya. Selain itu siswa MAY menemukan bangun lain yaitu seperti trapesium, namun siswa MAY tidak mengetahui namanya. Contoh hasil kerja siswa dapat dilihat pada Gambar 9.

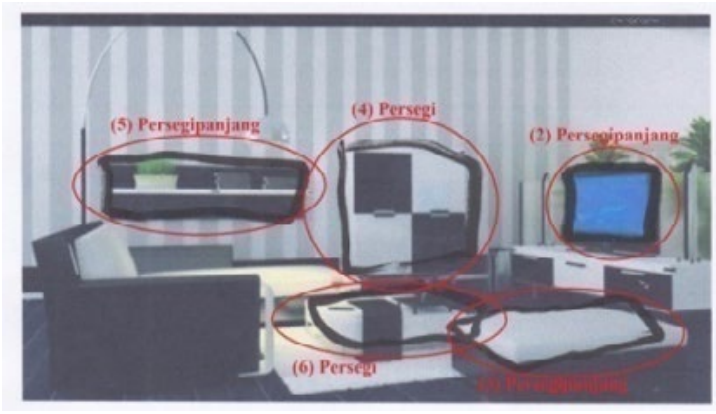

Gambar 9. Bentuk Segiempat pada Objek Nyata

Sementara itu kemampuan siswa MAY meniru bantuk yang dilihatnya cukup baik hanya kurang cermat dan teliti sehingga hasilnya kurang tepat. Selain itu siswa MAY hanya mampu menggambar bentuk bangun yang diketahuinya ketika diminta menggambar sebuah bangun segiempat.

Siswa MAY juga dapat membandingkan dua bangun segiempat menggunakan bahasanya sendiri dan juga menggunakan bahasa baku. Siswa MAY membandingkan bangun segiempat dengan menggunakan istilah ujung, panjang, lebar, maupun kecil. Selain itu siswa MAY juga dapat megidentifikasi bangun berdasarkan bagian atau komponen dengan menggunakan istilah sisi. Sementara ketika siswa MAY diminta mendeskripsikan sebuah bangun segiempat, siswa MAYmenggambarkan suatu bangun segiempat dengan menggunakan bahasa yang tidak baku atau menganalisis bagian-bagian bangun segiempat dan hubungannya menggunakan bahasanya sendiri. Hal tersebut dapat diketahui ketika siswa MAY mendeskripsikan suatu bangun segiempat mempunyai empat ujung, jajargenjang seperti rumah, ataupun menggunakan istilah panjang dan lebar. Selain itu siswa MAY juga sudah dapat melakukan analisis pada bangun segiempat dengan mengatakan mempunyai empat sisi ataupun menggunakan istilah mempunyai sisi sama. Kendala yang dihadapi siswa MAY adalah kesulitan dalam mendeskripsikan secara lisan dan mendeskripsikan tanpa melihat bangun yang dimaksud, hal tersebut dikarenakan siswa MAY tidak banyak mengenal bangun dan sering lupa.

Siswa MAY dapat dengan baik memecahkan masalah yang berhubungan dengan kemampuan visualisasi. Siswa MAY dapat membentuk bangun segiempat yang diminta menggunakan dua buah potongan segitiga. Kemampuan siswa MAY dalam memecahkan masalah juga dapat diketahui ketika dapat dengan baik mencari luas persegipanjang dengan pengubinan menggunakan satuan luas persegi.

\section{Analisis}

Hasil penelitian yang telah diperoleh menunjukkan siswa MAY belum sepenuhnya memahami komponen atau bagian dari bangun segiempat. Siswa MAY memahami yang dimaksud dengan sudut, namun siswa MAY tidak memahami komponen lain seperti sisi 
dan diagonal. Hal tersebut dapat diketahui ketika siswa MAY tidak dapat menunjukkan sisi dengan tepat dan siswa MAY tidak mengetahui yang dimaksud dengan diagonal. Siswa MAY juga belum dapat menentukan hubungan antarsudut pada bangun segiempat. Masalah tersebut membuat siswa MAY tidak dapat menentukan hubungan diantara komponen dan sifat bangun pada segiempat, dan juga membandingkan antarbangun segiempat menggunakan istilah dari hubungan diantara komponen maupun sifatnya.

\section{Temuan Lain}

Siswa tunagrahita mengetahui beberapa istilah yang ada pada bangun segiempat, namun mereka tidak mengetahui maksud dari istilah-istilah tersebut. Hal tersebut dapat dikarenakan siswa tunagrahita belum mendapat materi yang dimaksud dengan jelas ataupun sudah lupa, karena karakteristik mereka yang memiliki ingatan lemah. Kurangnya pengetahuan siswa tunagrahita tentang macam-macam bangun dan komponen-komponennya menghambat siswa dalam mengembangkan kemampuan berpikir geometrinya. Selain itu kemampuan berpikir geometri siswa tidak ditentukan pada tingkat/kelas dimana seorang siswa berada. Siswa dengan tingkat/kelas yang berbeda dapat memiliki kemampuan berpikir geometri yang sama.

\section{PENUTUP}

Berdasarkan analisis, pembahasan dan temuan dapat disimpulkan bahwa ketiga siswa tunagrahita cenderung memiliki kemampuan yang sama dalam berpikir geometri. Ketiga siswa tunagrahita dapat mencapai tingkat satu yaitu visualisasi berdasarkan tingkat berpikir geometri van Hiele, namun terbatas pada bentuk-bentuk bangun geometri yang dipahami atau dikenalnya.

Keadaan yang ada diatas menunjukkan butuhnya solusi untuk meningkatkan kemampuan siswa tunagrahita dalam belajar geometri. Oleh karena itu, sebaiknya guru lebih banyak mengenalkan macam-macam bentuk bangun pada siswa tunagrahita dan istilah-istilah baku dalam pembelajaran geometri. Selain itu guru perlu merancang pembelajaran matematika terutama pada materi geometri dengan memperhatikan tingkatan berpikir siswa tunagrahita, sehingga pembelajaran yang dilakukan lebih efektif.

\section{DAFTAR PUSTAKA}

Abdurrahman, Mulyono. (2010). Pendidikan Bagi Anak Berkesulitan Belajar. Jakarta: Rineka Cipta

Anggraeny, V. F. (2014). Profil Pemecahan Masalah Siswa Tunagrahita pada Pembelajaran Matematika dengan Menggunakan Pendekatan Formal dan Pendekatan Formal Divariasi Pendekatan Fungsional. Jurnal Elektronik Pembelajaran Matematika, 2(7), 740-749.

Badan Standar Nasional Pendidikan. (2006). Standar Isi untuk Satuan Pendidikan Dasar dan Menengah. Jakarta

Bramasti, R. (2012). Kamus Matematika. Surakarta: Aksara Sinergi Media

Crowley, M.L. (1987). The van Hiele Model of the Development of Geomemc Thought. Learning and Teaching Geometry, K-12, Yearbook of the National Council of Teachers of Mathematics, edited by Mary Montgomery Lindquist, pp.1-16. Reston, Va.: National Council af Teachers af Mathematics.

Delphie, B. (2006). Pembelajaran Anak Berkebutuhan Khusus. Bandung: Refika Aditama

Delphie, B. (2006). Pembelajaran Anak Tunagrahita. Bandung: Refika Aditama

Efendi, M. (2009). Pengantar Psikopedagogik Anak Berkelainan. Jakarta: Bumi Aksara

Kerami, D \& Sitanggang, C. (2003). Kamus Matematika. Jakarta: Balai Pustaka

Lestariyani, S. (2013). IdentifikasiTahap Berpikir Geometri Siswa SMP Negeri 2 Ambarawa Berdasarkan Teori Van Hiele (Doctoral dissertation, Program Studi Pendidikan Matematika FKIP-UKSW).

Maulani, R. H., Desmita, D., \& Kurnia, L. (2014). Analisis Tahapan Kognitif Van Hiele Pada Materi Bangun Ruang Di Mtsn Batu Tebal. Edusainstika, 1(1).

Muhassanah, N., Sujadi, I., \& Riyadi, R. (2014). Analisis Keterampilan Geometri Siswa Dalam Memecahkan Masalah Geometri Berdasarkan Tingkat Berpikir Van Hiele. Pembelajaran Matematika, 2(1), 54-66.

Somantri, T. S. (2006). Psikologi Anak Luar Biasa. Bandung: Refika Aditama

Sugiyono. (2010). Memahami Penelitian Kualitatif. Bandung: Alfabeta

Sugiyono. (2013). Motode Penelitian Pendidikan. Bandung: Alfabeta

Sutama, I. K., Suharta, I. G. P., Si, M., \& Suweken, G. (2014). Pengembangan Perangkat Pembelajaran Geometri SMA Berdasarkan Teori Van Hiele Berbantuan Wingeom dalam Upaya Meningkatkan Aktivitas dan Hasil Belajar Siswa. Jurnal Pendidikan Matematika, 3(1).

Utami, A. D. (2014). Strategi Guru Dalam Membelajarkan Matematika pada Materi Lingkaran Kepada Anak Tunagrahita (Studi Kasus pada Siswa Kelas VII SLB Muhammadiyah Cepu). Jurnal Elektronik Pembelajaran Matematika, 2(8), 853-864.

Walle, J.V.D. (2007). Matematika Sekolah Dasar dan Menengah Jilid 2. Jakarta: Erlangga 